\title{
THE INFLUENCE OF CLIMATE CHANGE ON THE HUMIDIFICATION REGIME OF THE STEPPE ZONE OF UKRAINE
}

\author{
Polovyi A. M., Ilina A. O.
}

\section{INTRODUCTION}

The problem of climate change assessment and developing the measures to adapt to these changes were recognized as priorities at the global level. These estimates are based on a variety of forecasts, which include climate and socio-economic forecasts, models of different complexity that describe the processes.

In recent decades in the European region several major research projects on regional climate modeling and the assessment of the consequences of its changing have been funded. As a result of these projects, the large-scale maps showing changes in such characteristics as average temperature and precipitation, crop yields, conditions for tourism, mortality due to the changes in a thermal regime, a loss of biodiversity, etc have been developed. The ENSEMBLES project offers the forecasts of climate changes in terms of changes in natural climate and a human influence on climate, and the PRUDENCE project identifies the consequences of future climate changing for different regions of Europe ${ }^{1,2}$. Currently, the EURO-CORDEX project also provides up-to-date model data with a high spatial resolution. Based on these data, a detailed analysis of future climate changes in Europe was performed $^{3}$.

1 ENSEMBLES: Climate Change and its Impacts: Summary of research and results from the ENSEMBLES project / Eds. P. van der Linden, J.F.B. Mitchell. UK, Exeter: Met Office Hadley Centre, 2009. 160 p.

${ }^{2}$ Christensen J.H., Christensen D.B. A summary of the PRUDENCE model projections of changes in European climate by the end of this century. Clim. Change. 2006. 81. № 1. P. 7-30.

${ }^{3}$ Jacob D., Petersen J., Eggert B., Alias A., Christensen O.B., Bouwer L.M., Braun A., Colette A., Déqué M. et al. EURO-CORDEX: new high resolution climate change projections for European impact research. Regional Environmental Change. 2014. Vol. 14. Issue 2. P. 563-578. DOI: 10.1007/s10113-013-0499-2. 
The PESETA project examines the effects of climate change on the following sectors: coastal systems, energy needs, a human health, agriculture, tourism and floods in the river basins. The PESETA project offers valuable data on the financial costs of climate change in Europe based on the current assessments of physical consequences and highly accurate climatic scenarios ${ }^{4}$.

It is noted ${ }^{5}$ that changes in the amounts of precipitation vary greatly between southern and northern Europe. In the south annual rainfall tends to decrease, there is a great risk of prolonged droughts, the difference between the years increases, and arid and semi-arid areas expand. In northern Europe, on the other hand, rainfall tends to increase, especially in winter. There is a wide region between them, where the changes are quite small on an annual basis, but the difference between the seasons is more pronounced there: winter and spring become wetter, while summer and less autumn become drier.

For the conditions of Ukraine Buksha I.F. ${ }^{6}$ notes that the amount of precipitation for the territory of Ukraine has changed insignificantly, but their nature and intensity has changed markedly. Balabukh V.O.' also points out that recently there has been an increase in the number of cases when half or a monthly rainfall falls in a few hours.

According to Shvydenko A. ${ }^{8}$ in Ukraine a decrease in total rainfall both on average per year and during the growing season should be expected. The most significant decrease will be in the southern regions

${ }^{4}$ Ciscar J.C et al. Climate change impacts in Europe. Final report of the PESETA research project. JRC Scientific and Technical Reports. European Commission Joint Research Centre Institute for Prospective Technological Studies, Institute for Environment and Sustainability, 2009. DOI: 10.2791/7409.

${ }^{5}$ Dankers R., Hiedere R. Extreme Temperatures and Precipitation in Europe: Analysis of a High-Resolution Climate. Change Scenario. European Commission Joint Research Centre Institute for Environment and Sustainability. Luxembourg: Office for Official Publications of the European Communities. European Communities, 2008. 67 p.

6 Букша I.Ф. Україна та глобальний парниковий ефект. Вразливість i адаптація екологічних та економічних систем до змін клімату / І.Ф. Букша, П.Ф. Гожик, Ж.Л. Смельянова. Київ, 1998. Книга 2. 208 с.

7 Балабух В.О. Зміна інтенсивності конвекції в Україні: причини та наслідки, 2008. URL : http://meteo.gov.ua/files/content/docs/Vinnitsa/UkrGMI.pdf. (дата звернення: 18.05.2021).

${ }^{8}$ Shvidenko A. Non-boreal Forests of Eastern Europe in a Changing World: the Role in the Earth Systems / Regional Aspects of Interactions in Non-boreal Eastern Europe. Springer Science+Business Media B.V., 2009. P. 123-133. 
of the country. After 2040 the amount of precipitation should increase slightly in winter, in the summer period their amount will remain within normal limits.

It should be noted that in Ukraine over the past decade, a comprehensive study of climate changes and their impacts on the economy of Ukraine has been carried out. In the works ${ }^{9,10}$ according to various climatic scenarios (A1B, A2, GFDL-30\%) a change in a precipitation regime in the soil-climatic zones of Ukraine was rather detaily considered in comparison with the period of 1986-2005. At a later date ${ }^{11}$, a study using the latest climatic change scenarios compared to the period of 1986-2005 was also carried out.

The steppe zone of Ukraine (Fig. 1) lies to the south of the ForestSteppe and stretches to the Azov-Black Sea coast and the Crimean Mountains. The steppe occupies $40 \%$ of the territory of Ukraine. The natural features of the steppe zone were affected by its position in the south of the Eastern European plain, where the steppe landscapes were formed in the conditions of unequal surface: the southern slopes of the Dnieper and Podil uplands, the Black Sea lowlands, the Donetsk and Azov uplands, the North Crimean plain.

Steppe landscapes were formed in hot climates with a negative moisture balance. According to the peculiarities of the landscape structure, conditions of moisture and thermal resources, the nature of soil cover and natural vegetation, as well as the peculiarities of agricultural use, the steppe zone is divided into three subzones: the Northern Steppe, the Middle Steppe and the Southern Steppe (dry steppe).

The Northern Steppe is a transition between the Forest-Steppe and the Steppe. It lies within the boundaries of Odessa, Mykolaiv, Kirovohrad, Dnipropetrovsk, Donetsk, Luhansk and Zaporizhia regions. The Middle Steppe, which includes parts of Odessa, Mykolaiv, Kherson, Zaporizhia and Dnipropetrovsk regions. The Black Sea steppe massif is almost entirely located within the administrative boundaries of Odessa, Mykolaiv and Kherson regions.

9 Оцінка впливу кліматичних змін на галузі економики України / C.М. Степаненко, А.М. Польовий. Одеса : «Екологія», 2011. 694 с.

10 Кліматичні зміни та їх вплив на сфери економіки України. / С.М. Степаненко, А.М. Польовий). Одеса : «ТЕС», 2015. 518 с.

${ }^{11}$ Кліматичні ризики функціонування галузей економіки України в умовах зміни клімату / С.М. Степаненко, А.М. Польовий. Одеса : «ТЕС», 2018. 546 с. 


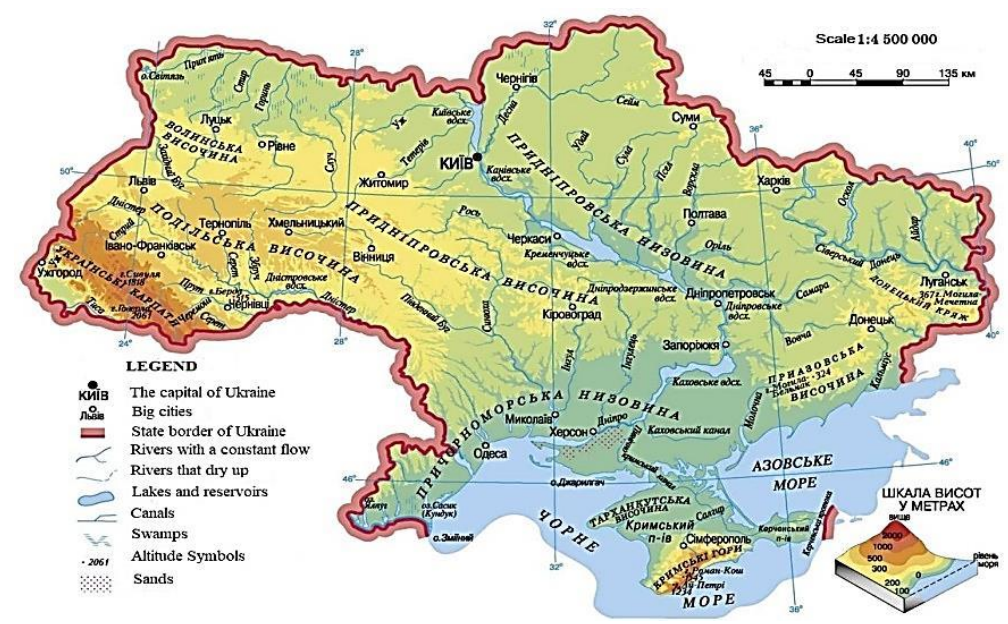

Fig. 1. The main landforms of Ukraine

We studied a humidification regime of three subzones of the Steppe zone: the Northern Steppe, the Middle Steppe and the Southern Steppe.

Scenarios (RCP4.5 and RCP8.5), namely Representative Concentration Pathways (RCP) are used for climate calculations and assessing the changes in the moisture resources ${ }^{12}$.

The study of the impact of climate change on the moisture resources were carried out by comparing the indicators under baseline conditions (period 1986-2015) ${ }^{13}$ and the data from climatic scenarios RCP4.5 and RCP8.5 (2021-2050).

To assess a moisture regime of the steppe zone, the following indicators were considered:

1) the amount of precipitation for periods with temperatures above $5^{\circ} \mathrm{C}$ and $10^{\circ} \mathrm{C}$, for the calendar seasons of the year and for the year;

2) total evaporation and vaporization, the evaporation deficit during the growing season of spring grain crops;

3) a moisture provision indicator - Selyaninov's hydrothermal coefficient (SHC), which is the amount of precipitation divided by the

12 Оцінка динаміки вуглецю та викидів CO2 в польовій сівозміні в умовах зміни клімату: колективна монографія. А.М. Польовий, Л.Ю. Божко, О.А. Барсукова. Полтава, 2019. С. 122-130.

13 Агрокліматичний довідник по території України. Київ, 2019. 81 с. 
sum of temperatures above $10^{\circ} \mathrm{C}$ reduced by 10 times, which is assumed to be equivalent to the evaporation.

Output data. For this study, the materials included in the meteorological yearbooks for the period 1986-2015 were used. Agrometeorological research is based on data on the duration of sunshine, the average daily air temperature, precipitation, relative humidity and the deficit of water vapor saturation in the air for decades. Meteorological data of 28 meteorological stations, evenly distributed on the territory of the Steppe zone of Ukraine, which fully reflect the local features of the territory, were used for the research. The location of meteorological stations is presented in Figure 2: data from five meteorological stations were used in Odesa region, four in Mykolaiv, Kherson, Donetsk and Luhansk regions, three in Dnipropetrovsk and Zaporizhia regions, and one in Crimea. As can be seen from the layout of meteorological stations, we selected 3-5 stations for each region.

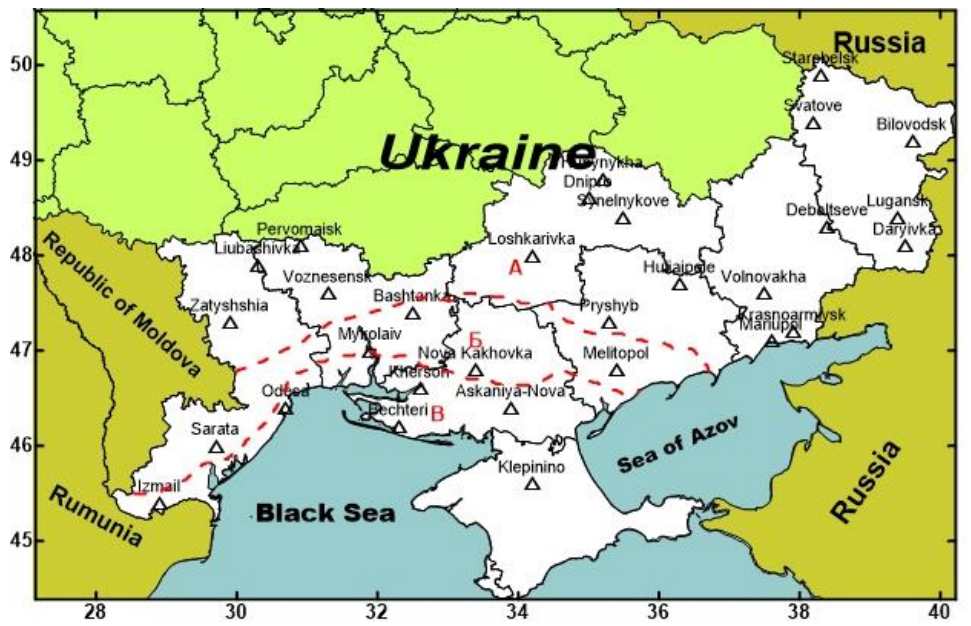

Fig. 2. Map-scheme of location of meteorological stations (by author)

\section{Determination of moisture supply of the study area}

On the territory of the Northern Steppe subzone, according to climatic change scenarios RCP4.5 and RCP8.5 the annual rainfall is expected to decrease by $10-11 \%$ compared to the base period. This change in the amount of precipitation will be unevenly distributed over the seasons: in winter the amount of precipitation will increase (by 19-21\%) relative to 
the base value and will be 131-133 mm compared to $110 \mathrm{~mm}$ observed in the base period. Under the RCP4.5 climatic scenario, it will decrease (by 12\%) in spring and for the RCP8.5 climatic scenario the amount of spring precipitation will slightly increase (from $128 \mathrm{~mm}$ to $129 \mathrm{~mm}$ ). In summer in the scenario periods (RCP4.5 and RCP8.5) the amount of precipitation is expected to decrease significantly (by 35-36\%) compared to the base period and it will be 101-104 mm. In autumn for the RCP4.5 climatic scenario a slight $(2 \%)$ decrease in precipitation is expected. Under the RCP8.5 climatic scenario a harsher precipitation regime is expected in autumn. Thus at the climatic norm of $120 \mathrm{~mm}$ in autumn, the precipitation is expected to be reduced to $101 \mathrm{~mm}$, i.e. by $16 \%$.

During the period with air temperatures above $5^{\circ} \mathrm{C}$ and $10^{\circ} \mathrm{C}$, the amount of precipitation will decrease by $22-27 \%$ and $26-33 \%$, respectively. The total evaporation for the period with air temperature above $10^{\circ} \mathrm{C}$ will decrease by $24-26 \%$, evaporation will increase by $12-$ $13 \%$, and the evaporation deficit will increase from $347 \mathrm{~mm}$ to $522-539$ $\mathrm{mm}$ (by 50-55\%). The hydrothermal coefficient will decrease compared to the base value from 0.88 . to 0.69 and 0.65 relative value. Moreover this decrease will be greater for the RCP8.5 scenario.

Under the conditions of climate change, a significant change in the amount of precipitation is expected on the territory of the Central Steppe subzone. There will be a decrease in the annual rainfall from $498 \mathrm{~mm}$ to $433 \mathrm{~mm}$ and $427 \mathrm{~mm}$ respectively in the RCP4.5 and RCP8.5 climatic scenarios. This will be a decrease of $13-14 \%$ compared to the climatic norm.

According to the seasonal distribution, a significant decrease in the amount of precipitation is expected for all seasons under the RCP4.5 scenario. In winter according the RCP4.5 scenario there will be no significant $(2 \%)$ decrease in the amount of precipitation, while in spring it will reach $12 \%$. The change in the amount of summer precipitation is expected to be especially large: the decrease from $133 \mathrm{~mm}$ to $88 \mathrm{~mm}$, i.e. by $34 \%$. Autumn decrease in the precipitation amount will be insignificant (by 3\%).

According to the RCP8.5 climatic scenario, there will be an increase in precipitation from $127 \mathrm{~mm}$ to $138 \mathrm{~mm}$ in winter (by 9\%), in spring this increase will be insignificant (by 2\%). In summer, as in the RCP4.5 climatic scenario, a significant (up to $36 \%$ ) decrease in precipitation from $133 \mathrm{~mm}$ to $85 \mathrm{~mm}$ is expected. The same significant decrease in the amount of precipitation will be observed in autumn: from $116 \mathrm{~mm}$ to 80 $\mathrm{mm}$ (by $31 \%$ ). 


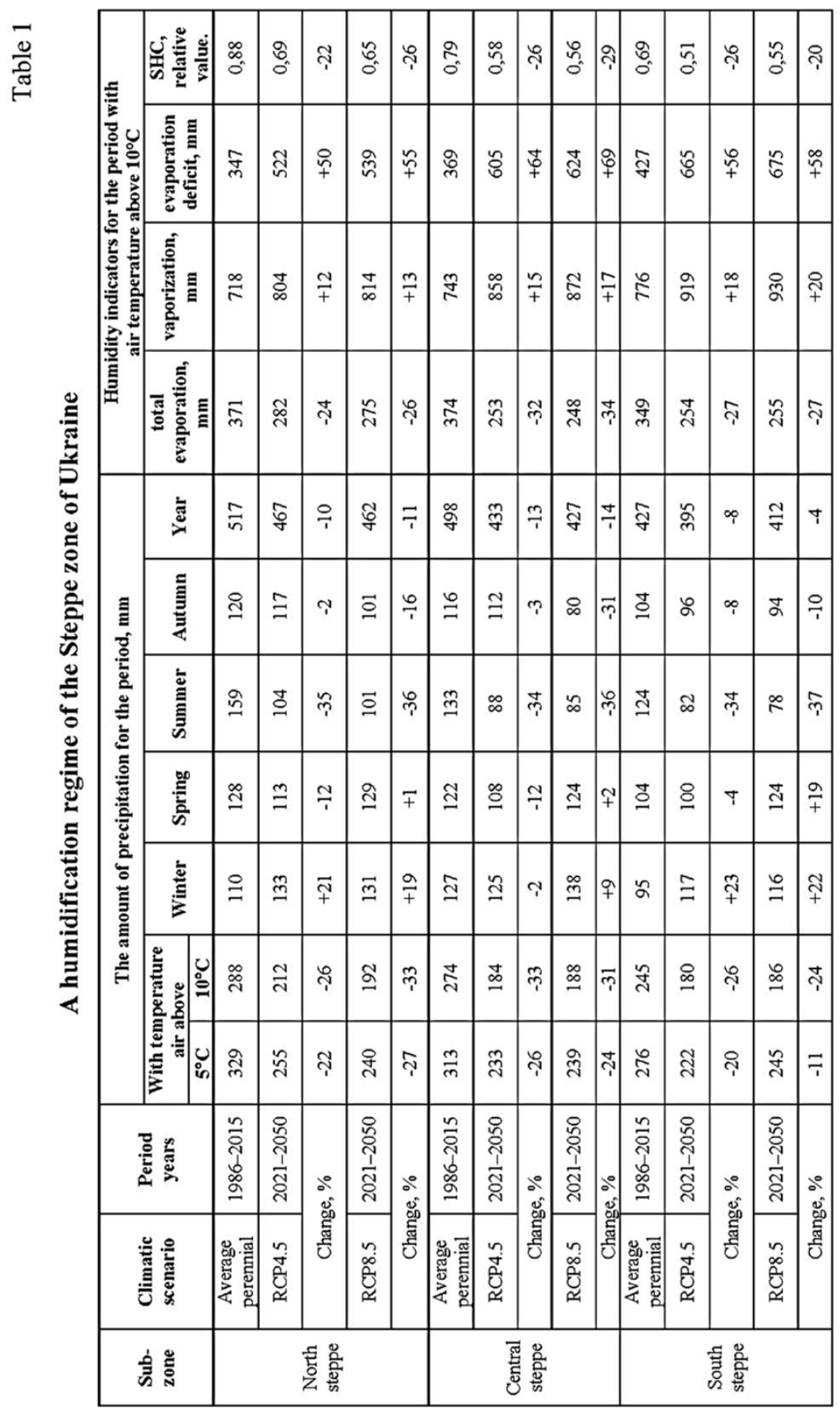


For the period with air temperatures above $5^{\circ} \mathrm{C}$ and $10^{\circ} \mathrm{C}$, the amount of precipitation will decrease by $24-26 \%$ and $31-33 \%$, respectively. This decrease will be slightly smaller for the RCP8.5 scenario. For the period with air temperature above $10^{\circ} \mathrm{C}$, the total evaporation will decrease from $374 \mathrm{~mm}$ to $248-253 \mathrm{~mm}$ (by $32-34 \%$ ), vaporization will relatively increase: according to the climatic norm it was $743 \mathrm{~mm}$, it is expected to increase to $858 \mathrm{~mm}$ under the RCP4.5 scenario and up to $872 \mathrm{~mm}$ in the RCP8.5 scenario. All this will lead to the fact that in both climatic scenarios there will be an increase in the evaporation deficit by $64-69 \%$ and a decrease in the hydrothermal coefficient from 0.79 to $0.56-0.58$ relative value.

In the territory of the South-Steppe subzone, the decrease in annual precipitation will be slightly less compared to the North-Steppe and the Central-Steppe subzones. It will be a decrease of $4-8 \%$ compared to the climatic norm, which is $427 \mathrm{~mm}$.

During the seasons the distribution of precipitation will be unequal. In winter according to both scenarios, the amount of precipitation will increase significantly (by 22-23\%) and it will be 116-117 $\mathrm{mm}$. In the spring according to the RCP4.5 climatic scenario precipitation is expected to decrease by $4 \%$ (up to $100 \mathrm{~mm}$ compared to the climatic norm of $104 \mathrm{~mm}$ ). Characteristically for the RCP8.5 climatic scenario, there will be an increase in precipitation in all subzones in spring. In the Southern steppe subzone, this increase will be quite significant (up to 19\%). At the climatic norm of $104 \mathrm{~mm}$, the precipitation is expected to be $124 \mathrm{~mm}$. The summer period will be characterized by a sharp (34-37\%) decrease in precipitation compared to the climatic norm. Under scenarios RCP4.5 and RCP8.5, precipitation is expected to be 82 and $78 \mathrm{~mm}$, respectively. In the autumn season the amount of precipitation will also be decreased to 96 and $94 \mathrm{~mm}$ compared to the base value (by $8-10 \%$ ).

The period with air temperatures above $5^{\circ} \mathrm{C}$ and $10^{\circ} \mathrm{C}$ is also characterized by a decrease in precipitation by $11-20$ and $24-26 \%$. For the period with air temperature above $10^{\circ} \mathrm{C}$ there will be a decrease in total evaporation from $349 \mathrm{~mm}$ to $254-255 \mathrm{~mm}$ (by 27\%) and an increase in vaporization. According to the climatic norm, vaporization was $776 \mathrm{~mm}$, but in the scenario periods it is expected to be $919-930 \mathrm{~mm}$, which is $18-20 \%$ higher than the climatic norm. In this situation, in both climatic scenarios, there will be an increase in the evaporation deficit by $56-58 \%$ and a decrease in the hydrothermal coefficient from 0.69 to 0.51-0.55 relative value. Compared to the RCP8.5 climatic scenario, it will be drier when implementing the RCP4.5 scenario. 
Moisture resources are very variable both in territory and in time. Therefore, a comprehensive study of moisture resources and their proper consideration and use for agricultural production is important. Figures 3 and 4 show the changes in precipitation in the steppe zone of Ukraine during the period with air temperatures above $5^{\circ} \mathrm{C}$ in the context of climate change. As a result of the carried out work it is revealed that on the investigated territory decrease in quantity of precipitations will be observed.

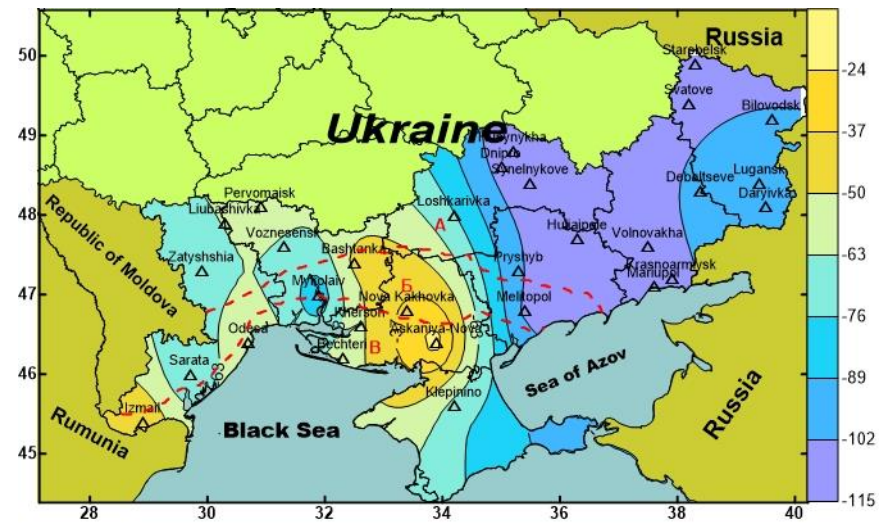

Fig. 3. A map of the difference in precipitation $(\mathrm{mm})$ in the South of Ukraine according to the scenario RCP 4.5. $A$ - the North-Steppe subzone, B - the Central-Steppe subzone, $C$ - the South-Steppe subzone

Figure 3 shows that under the RCP 4.5 scenario the maximum precipitation reduction (up to $30 \%$ ) will be observed in Donetsk and Dnipropetrovsk regions belonging to the North Steppe subzone and in Zaporizhia region belonging to the Central Steppe subzone. In the Central steppe subzone, the amount of precipitation will decrease by about 20\% (Mykolaiv, Odesa regions). In the southern regions, the amount of precipitation will decrease by $5-15 \%$.

According to the RCP 8.5 scenario, the amount of precipitation for the period 2021-2050 indicates an oscillating mechanism with a reduction interval of $15-125 \mathrm{~mm}$ (Fig. 4). The amount of precipitation will decrease significantly in the Northern part of the Steppe zone of Ukraine $(85-105 \mathrm{~mm})$ and a slight increase in precipitation will be observed in part of the Kherson and Odessa regions, which are part of 
the Southern steppe subzone. It will increase only in part of the Black Sea lowlands and in the Crimea. Their decrease will be observed on the territory of the Ukrainian Shield and Donetsk Ridge.

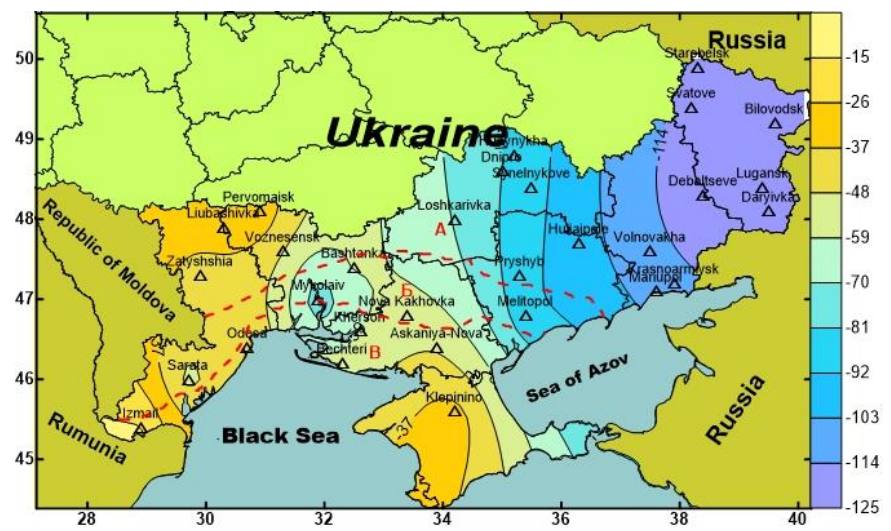

Fig. 4. A map of the difference in precipitation $(\mathrm{mm})$ in the South of Ukraine according to the scenario RCP 8.5. $A$ - the North-Steppe subzone, B - the Central-Steppe subzone, $C$ - the South-Steppe subzone

Analysis of the forecast period (2021-2050) of the annual course of precipitation and its changes in the steppe zone of Ukraine indicates that changes in precipitation amounts are observed in significant limits: from the maximum difference of $123 \mathrm{~mm}$ in the North Steppe subzone to 14 $\mathrm{mm}$, which is observed in arid areas of the South Steppe subzone. Such variability may be due to the heterogeneity of the physical and geographical conditions of the territory, which directly affect its moisture regime.

\section{Assessment of aridity of the territory with the help of SHC}

One of the characteristics of the humidification regime of crops is the value of the hydrothermal coefficient (SHC), which is the ratio of precipitation to the sum of average daily air temperatures above $10{ }^{\circ} \mathrm{C}$, multiplied by 0.1. The value of SHC for the period from May to August characterizes the conditions of moisture for the most critical period of growth and development of plants and is closely related to the yield of early spring crops. 
The SHC value given in table 1 characterizes the humidity of the territory according to the climatic and scenario data for the period with air temperature above $10^{\circ} \mathrm{C}$. It gives a fairly good idea of the aridity of the Steppe subzones in Ukraine, but it does not reproduce the dynamics of the process. Figure 5 shows the assessment of the aridity of the period of growth and development of plants in the steppe zone of Ukraine (a North-steppe subzone, b - Central steppe subzone, c - South-steppe subzone).

The humidification conditions of the North-Steppe subzone in the base period were more favorable than in the period 2021-2050. The average value of the SHC of the base period is 0.91 , which characterizes the sufficient humidification of the territory. (Fig. 5a). For the forecast period (2021-2050), the territory of the North Steppe subzone under both the RCP 4.5 scenario and the RCP 8.5 scenario will be marked by a moderate drought, and the average SHC value will be $0.70-0.76$.

According to our forecasts in the Central Steppe subzone, in the scenario climatic periods RCP4.5 and RCP8.5, the number of decades with severe drought will increase to eight, and three to four decades with very severe drought are expected. According to scenario calculations, the period when the SHC will be greater than 1.0 (sufficient humidification conditions) will be only $2-3$ decades out of 18 , namely only $17 \%$. The average value of SHC in the scenario climate period RCP4.5 will be equal to 0.65 , and in the scenario period RCP8.5 - 0.6 (moderate drought) (Fig. 5b).

In the South-steppe subzone in the conditions of climate change there will be some increase in aridity (Fig. 5c). If in the base period for the period April - September was characterized by 3 decades with severe drought, then in the implementation of climate scenarios drought (medium and severe drought) will be observed for almost four months (June, July, August, September). The average value of SHC in the scenario climate period RCP4.5 will be equal to 0.58 , and in the scenario period RCP8.5 - 0.59, which is characterized by severe drought for the study area. 


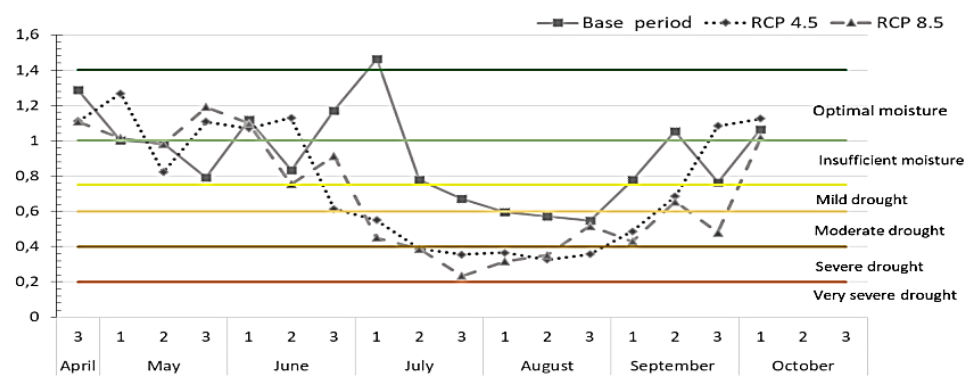

A) The North-Steppe subzone

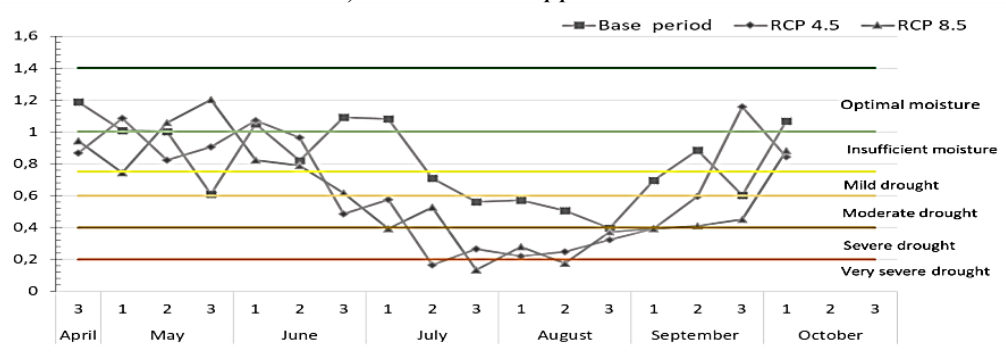

B) The Central-Steppe subzone

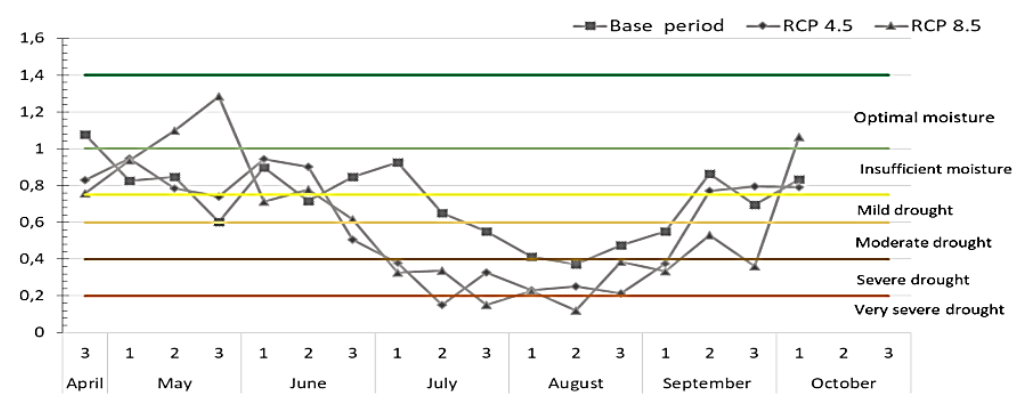

C) The South-Steppe subzone

Fig. 5. Assessment of aridity of the vegetation period by decades in the Steppe zone of Ukraine (a - the North-Steppe subzone, $b$ - the Central-Steppe subzone, $c$ - the South-Steppe subzone)

\section{CONCLUSIONS}

The aim of the study was to determine the degree of humidification of the steppe zone of Ukraine in the context of climate change. For this purpose, a long-term series of observations was used, which allows to 
establish quite reliable characteristics of the degree of humidity and aridity of the territory. At the same time, climatic, soil and physical-geographical characteristics of separate subzones were taken into account.

A comparison of humidification conditions in the period of 19862015 and the climatic scenarios RCP4.5 and RCP8.5 showed that there will be a rather significant redistribution of the amount of precipitation over the seasons. There will be an increase in their number in winter and spring and their number will sharply decrease in the summer period, they will also decrease in the autumn period.

It is established that the period with air temperature above $5^{\circ} \mathrm{C}$ and $10^{\circ} \mathrm{C}$ is also characterized by a decrease in the amount of precipitation by $11-20$ and $24-26 \%$. For the period with air temperature above $10^{\circ} \mathrm{C}$ there will be a decrease in total evaporation from $349 \mathrm{~mm}$ to 254-255 mm (by 27\%) and an increase in vaporization. According to the climatic norm, vaporization was $776 \mathrm{~mm}$, in the scenario periods it is expected to be $919-930 \mathrm{~mm}$, which is $18-20 \%$ higher than the climatic norm. In this situation, in both climate scenarios, there will be an increase in the evaporation deficit by $56-58 \%$ and a decrease in the hydrothermal coefficient from 0.69 to $0.51-0.55$ relative value. With the implementation of climatic scenarios RCP4.5 and RCP8.5 from the North-Steppe to the South-Steppe subzone the number of arid decades including very strong ones will increase.

For the base period in the North-Steppe subzone, the SHC characterizes the conditions of sufficient moisture, sometimes insufficient moisture, in early spring. However in July and August there are four decades with mild and moderate drought. For the RCP4.5 climatic scenario aridity is increasing and moderate and severe droughts are expected to increase and will be observed throughout July, August and the first decade of September. Under the RCP8.5 climatic scenario, an increase in drought is also expected, and there may be a very severe drought within a decade.

For the Central-Steppe subzone under average long-term climatic conditions, the number of decades with weak and medium aridity will increase to six, and under scenario climatic periods RCP4.5 and RCP8.5 their number will increase to eight, with one or two decades are expected with a very severe drought.

The southern steppe subzone is characterized as quite arid in the base period, and when implementating the climatic scenarios, aridity (medium and severe drought) will be observed for almost three months (July, August, September). Even very severe droughts can occur in July and August. 


\section{SUMMARY}

The assessment of changes in agroclimatic resources, namely the conditions of humidification of the Steppe zone in Ukraine in 2021-2050 in connection with climate changes in comparison with the base period of 1986-2015 is considered. Climatic scenarios RCP4.5 and RCP8.5 (Representative Concentration Pathways - RCP) were used to assess the changes. An assessment of the moisture supply of the vegetation period was given. A comparison of the humidification conditions showed that the period of air temperature above $5^{\circ} \mathrm{C}$ is also characterized by a decrease in the amount of precipitation by 11-20 and 24-26\%. It has been established that under both climatic scenarios there will be an increase in the evaporation deficit by $56-58 \%$ and a decrease in the hydrothermal coefficient from 0.69 to $0.51-0.55$ relative value. With the implementation of climatic scenarios RCP4.5 and RCP8.5 the number of arid decades, including very strong ones will increase from the NorthSteppe subzone to the South-Steppe one.

\section{References}

1. ENSEMBLES: Climate Change and its Impacts: Summary of research and results from the ENSEMBLES project / Eds. P. van der Linden, J.F.B. Mitchell. UK, Exeter: Met Office Hadley Centre, 2009. $160 \mathrm{p}$.

2. Christensen J.H., Christensen D.B. A summary of the PRUDENCE model projections of changes in European climate by the end of this century. Clim. Change. 2006. 81. № 1. P. 7-30.

3. Jacob D., Petersen J., Eggert B., Alias A., Christensen O.B., Bouwer L.M., Braun A., Colette A., Déqué M. et al. EURO-CORDEX: new high resolution climate change projections for European impact research. Regional Environmental Change. 2014. Vol. 14. Issue 2. P. 563-578. DOI: 10.1007/s10113-013-0499-2.

4. Ciscar J.C et al. Climate change impacts in Europe. Final report of the PESETA research project. JRC Scientific and Technical Reports. European Commission - Joint Research Centre Institute for Prospective Technological Studies, Institute for Environment and Sustainability, 2009. DOI: $10.2791 / 7409$.

5. Dankers R., Hiedere R. Extreme Temperatures and Precipitation in Europe: Analysis of a High-Resolution Climate. Change Scenario. European Commission Joint Research Centre Institute for Environment and Sustainability. Luxembourg: Office for Official Publications of the European Communities. European Communities, 2008. 67 p. 
6. Букша I.Ф. Україна та глобальний парниковий ефект. Вразливість і адаптація екологічних та економічних систем до змін клімату / І.Ф. Букша, П.Ф. Гожик, Ж.Л. Смельянова. Київ, 1998. Книга 2. 208 c.

7. Балабух В.О. Зміна інтенсивності конвекції в Україні: причини та наслідки, 2008. URL : http://meteo.gov.ua/files/content/ docs/Vinnitsa/UkrGMI.pdf. (дата звернення: 18.05.2021)

8. Shvidenko A. Non-boreal Forests of Eastern Europe in a Changing World: the Role in the Earth Systems / Regional Aspects of Interactions in Non-boreal Eastern Europe. Springer Science+Business Media B.V., 2009. P. 123-133.

9. Оцінка впливу кліматичних змін на галузі економики України / С.М. Степаненко, А.М. Польовий. Одеса : «Екологія», $2011.694 \mathrm{c}$.

10.Кліматичні зміни та їх вплив на сфери економіки України. / С.М. Степаненко, А.М. Польовий). Одеса : «ТЕС», 2015. 518 с.

11.Кліматичні ризики функціонування галузей економіки України в умовах зміни клімату / С.М. Степаненко, А.М. Польовий. Одеса : «ТЕС», 2018. 546 с.

12. Оцінка динаміки вуглецю та викидів $\mathrm{CO}_{2}$ в польовій сівозміні в умовах зміни клімату : колективна монографія / А.М. Польовий, Л.Ю. Божко, О.А. Барсукова. Полтава, 2019. С. 122-130.

13.Агрокліматичний довідник по території України. Київ, 2019. $81 \mathrm{c}$.

\section{Information about the authors: Polovyi Anatolii Mykolaiovych,} Doctor of Sciences in Geography, Professor, Head of the Department of Agrometeorology and Agroecology Odesa State Environmental University 15, Lvivska str., Odesa, 65016, Ukraine

Ilina Anna Oleksandrivna, Postgraduate Student at the Department of Ecology and Environmental Protection Odesa State Environmental University 15, Lvivska str., Odesa, 65016, Ukraine 